\title{
IMPLEMENTASI ALGORITMA APRIORI PADA DATA PENJUALAN PRODUK ASESORIS CV PRINCES DIARY SAMARINDA
}

\author{
Siti Qomariah ${ }^{1)}$, Basrie $^{2)}$, Srinita Fitriani Pa'a ${ }^{3)}$ \\ ${ }^{1,3)}$ Teknik Informatika, STMIK Widya Cipta Dharma-Samarinda \\ ${ }^{2)}$ Sistem Informasi, STMIK Widya Cipta Dharma-Samarinda \\ sitiqom@wicida.ac.id ${ }^{1)}$
}

\begin{abstract}
Abstrak - CV Princes Diary adalah perusahaan yang bergerak pada penjulan produk asesoris yang beragam, ada 25 jenis barang yang dijual pada toko mereka, tetapi data penjulan tersebut belum dianalisa dengan baik untuk menghasilkan strategi penjualan yang meningkatkan keuntungan untuk perusahaan. Salah satu algoritma dalam data mining adalah algoritma apriori. Datamining banyak diimplementasikan dalam berbagai bidang seperti bisnis, perdagangan, dan lain-lain. penelitian ini bertujuan untuk membuat aplikasi dengan penerapan metode data Mining dengan algoritma apriori untuk mengolah data penjualan tersebut lebih terstruktur, terinci dan mengetahui permasalahan pada penjualan produk. Penelitian ini dilakukan mencari pola informasi transaksi produk, sehingga mengahasilkan stok barang yang harus diperbanyak atau dikurangi. Algoritma apriori adalah salah satu cabang dari data minning yang berfungsi mencari pola informasi dari banyaknya data yang dimikili. Market basket analisis adalah salah satu teknik dari data mining dengan strategi cross- selling dimulai dengan mencari sejumlah frequent itemset dan dilanjutkan dengan patter Growth. untuk tool penelitian yang digunaka adalah rapid miner. Intensitas penjulana produk yang didapat mengunakan algoritma apriori dengan market basket analisis. Pada CV Princes Diary produk yang dijual adalah produk asesoris seperti dompet, kacamata, kalung dan lain-lain. pada hasil penelitian ditemukan enam aturan 6 buah aturan atau rule yang bisa digunakan untuk strategi penjulan Jika membeli kaca mata maka akan membeli dompet ( dengan nilai support 52,5\% dan confidence 55,9\%) Jika membeli tali sepatu maka akan membeli make up dengan nilai support 55,9\% dan confidence 56,4\%) Jika membeli make up, Maka akan membeli alat make up dan sisir ( dengan nilai support 56,4\% dan confidence $61,6 \%$ ) Jika membeli sisir maka akan membeli make up ( dengan nilai support 61,6\% dan confidence 65,3\%) Jika membeli Make Up, maka akan membeli sisir dan Alat Make up ( dengan nilai support 65,3\% dan confidence 65,3\%) Jika membeli Make Up, Maka membeli sisir dan alat make up ( dengan nilai support 82,5\% dan confidence 82,5\%) informasi pola frekuensi asosiasi tertinggi adalah jika membeli make up maka maka membeli sisir dengan nilai support sebesar $8.825 \%$ dan nilai conficende $0.825 \%$. dengan aturan diatas produk pertama dan produk kedua bisa disandingkan untuk promosi pendualan dengan harga yang menarik
\end{abstract}

Kata Kunci - Data minning, Apriori, Rapid Miner

\section{PENDAhUluaN}

Persaingan dunia usaha khusunya bidang penjualan menuntut setiap usaha untuk cerdik dalam penerapan strategi penjulan yang mendatangkan keuntungan yang tinggi. persediaaan barang, pengaturan rak barang adalah salah satu dari strategi penjulan yang bisa menarik minat konsumen untuk berbelanja. Princes Diary adalah perusahaan yang bergerak dibidang penjulan assesoris. Penjualan merupakan kegiatan yang terinegrasi untuk mengembangkan rencana-rencana penting yang ditujukan kepada pembeli atau konsumen, gunanya adalah untuk memperoleh penjualan yang bisa menghasilkan keuntungan atau laba. Untuk itu di perlukaannya perhitungan, strategi dan perencanaan untuk mendapatkan hasil penjualan yang menguntungkan bagi pihak Perusahaan, yang berupa pengolahan data yang integratif yang dapat membantu pihak perusahaan dalam menjual suatu produk

Pada penelitian [1] dengan judul implementasi data mining dengan metode algoritma Apriori dalam menentukan pola pembelian obat dengan hasil penelitian berupa perhitungan dengan sistem yang dibangun ditentukan nilai minimum support: 50 $\%$ dan nilai minimum confidence $70 \%$ maka dihasilkan kecenderungan obat yang dibeli oleh konsumen. Dari hasil tersebut maka sistem ini dapat membantu pola pembelian obat berdasarkan kecenderungan obat yang dibeli konsumen yang terdiri dari 2 itemset obat, kemudian dari hasil pengujian ini juga dapat membantu pihak karyawan dalam mengatur tata letak obat yang terdiri dari 2 itemset obat secara berdekatan untuk memudahkan karyawan dalam mengetahui keberadaan obat.

Pada penelitian [2] penerapan metode datamining market basket analysis terhadap data penjualan produk buku dengan mengunakan 
algoritma apriori dan Frequent Pattern Growth (FPGrowth) studi kasus percetakan PT Gramedia disimpulkan kekuatan aturan asosiasi yang dihasilkan algoritma apriori lebih besar dibandingkan dengan algoritma FP- Growth, penyebabnya adalah rendahnya nilai support. Tingkat akurasi dari algoritma apriori terhadap FP-Growth adalah $257,4543 \%$.

Pada penelitian [3] penerapan metode datamining metode apriori menghasilkan aturanaturan atau rule yang dapat diimplementasikan dalam pembuatan program apliakasi penjulan yang tidak hanya mencatat transaksi data tetapi juga Aplikasi ini menghasilkan aturan-aturan yang membantu penarikan kesimpulan yang dibutuhkaan untuk penarikan kesimpulan informasi strategi bagi perusahaan berkenaan dengan data penjualan

\section{METODE}

\subsection{Data minning}

Data mining didefinisikan sebagai proses menemukan pola-pola dalam data, dimana proses-nya harus otomatis atau semi-otomatis. Pola-pola yang ditemukan harus berarti dan menghasilkan keuntungan [4]. Data mining adalah pencarian dan teknik analisa data yang besar untuk menemukan pola dan aturan yang berarti. Pola-pola yang dimaksud dapat diperoleh dari berbagai macam basis data seperti basis data relasional, data warehouse, data transaksi, dan data berorientasi objek. Dari pernyataan sebelumnya dapat disimpulkan bahwa data mining selalu berhubungan dengan penemuan informasi atau pengetahuan baru dalam database, baik secara otomatis maupun semi otomatis. Tahapan dalam dataminning adalah sebagai berikut :

\section{a. Data cleaning (pembersihan data)}

Pada kenyataannya, data yang didapat dari suatu database belum tentu memiliki kualitas yang cukup baik. Misalnya data tersebut tidak lengkap atau ada informasi yang hilang, maupun data tidak valid, juga terdapat atributatribut data yang tidak relevan terhadap teknik data mining yang digunakan. Data cleaning bertujuan untuk membuang data-data yang tidak konsisten, menghilangkan noise dan melengkapi data yang kehilangan informasi, sehingga performansi dari data mining dapat meningkat [5]. Pada penelitian ini yang dilakukan adalah pemilihan atribut yaitu atribut nomor transaksi penjualan \& nama barang, sehingga atribut yang tidak digunakan akan dihapus, selain itu juga dilakukan perbaikan untuk data-data yang rusak atau kurang tepat.

\section{b. Data integration (integrasi data)}

Data yang akan diproses dalam data mining dapat berasal dari berbagai database, dan bukan hanya dari satu database [6]. Integrasi data diperlukan untuk menggabungkat data dari berbagai sumber data kedalam satu database baru. Integrasi yang teliti dapat mengurangi dan menolak redundansi data, sehingga dapat meningkatkan akurasi dan kecepatan dari proses data mining. Pada penelitian ini proses untuk mengintegrasikan data transaksi penjualan pada Princes Diary dengan Rapid Miner, yaitu diubah dalam bentuk tabulasi dengan Ms. Excell.

\section{c. Data selection (pemilihan data)}

Sering kali terdapat data yang tidak terpakai dalam database. Hanya data yang sesuai untuk dianalisis yang diperlukan.[7] Sebagai contoh, untuk meneliti kebiasaan beli konsumen, tidak perlu mengambil data nama konsumen, cukup dengan id konsumen saja. Dalam kasus market basket analysis, kuantitas barang dan harga kurang begitu diperlukan. Pada penelitian ini hanya no transaksi dan nama barang atau item barang

\section{d. Data transformation (transformasi data)}

Pada tahapan ini, data diubah atau ditransformasikan menjadi format data yang sesuai untuk diproses dalam data mining, sebab ada metode-metode data mining yang memerlukan format data tertentu untuk diolah. Proses mentransformasikan data yang telah dipilih sehingga sesuai untuk data mining adalah coding. Proses coding dalam KDD sangat tergantung pada jenis atau pola informasi yang akan dicari dalam basis data.

\section{e. Data mining (penggalian data)}

Metode dan algoritma yang telah ditentukan mulai diterapkan untuk mencari pola dan menemukan informasi berharga yang tersembunyi. Pemilihan metode atau algoritma yang tepat sangat bergantung pada tujuan dan proses KDD secara keseluruhan.

\section{f. Pattern Evaluation (evaluasi pola)}

Pola informasi yang dihasilkan dari proses data mining mungkin berbeda dan tidak sesuai dengan hipotesa [8]. Bila hal ini terjadi, hasil tersebut dapat dijadikan umpan balik untuk memperbaiki proses data mining. Solusi lain adalah dengan mengubah metode yang digunakan, atau menerima hasil yang ada sebagai pengetahuan baru yang mungkin dapat bermanfaat.

\section{g. Knowledge presentation.}

Knowledge presentation merupakan tahapan akhir dalam proses data mining. Bagaimana 
pengetahuan yang telah ditemukan akan disajikan kepada user [9]. Tidak semua user memahami data mining, karenanya penting untuk menyusun dengan baik penyajian hasil data mining dalam bentuk yang dapat dipahami oleh user. Dalam hal ini, visualisasi juga dapat digunakan untuk membantu menyampaikan hasil data mining.

\subsection{Algoritma Apriori}

Dalam bukunya [10] mengemukakan bahwa algoritma Apriori adalah salah satu algoritma yang dapat digunakan pada penerapan market basket analysis untuk mencari aturan-aturan asosiasi yang memenuhi batas support dan confidencegv. Selama proses tahap petama, algoritma menghasilkan penggalian secara sistematis tanpa menjelajahi semua kandidat, sedangkan pada tahap kedua dilakukan ekstraksi terhadap aturan yang kuat. Frequent itemset biasanya mengacu pada kumpulan item yang sering muncul bersamaan dalam sebuah data transaksional. Contohnya jika item A dan B sering dibeli bersamaan dalam suatu toko.Setelah menemukan frequent itemset, algoritma ini kemudian meneliti knowledge dari frequent item sebelumnya untuk menggali informasi selanjutnya. Apriori menggunakan pendekatan iteratif dengan level-wise search dimana kitemset dipakai untuk mencari $(\mathrm{k}+1)$-itemset. Iterasi i menghitung semua kumpulan data $\mathrm{i}$ (kumpulan yang mengandung elemen i) yang sering muncul. Setiap iterasi terdiri dari dua langkah yaitu candidate generation (penentuan kandidat) dan candidate counting and selection (pemilihan serta penghitungan kandidat) .

Parameter penting yang diperlukan untuk pembentukan rules dalam penerapan algoritma Apriori[11], yaitu :

\section{Support}

Support (nilai penunjang) merupakan persentase dari record-record yang mengandung kombinasi item dibanding dengan jumlah total record. Contoh jika terdapat kombinasi item A dan B, support dari $\{\mathrm{A}, \mathrm{B}\}$ adalah peluang sebuah transaksi yang mengandung item A dan B.

$$
\text { Support }(\boldsymbol{A})=\frac{\sum \text { transasksi } A}{\text { Total transaksi }} \times 100 \% \text { (1) }
$$

Persamaan (1) merupakan rumus umum untuk menghitung nilai support suatu item.

Support $(\boldsymbol{A})=\frac{\sum \text { transasksi Adan B }}{\text { Total transaksi }} \times 100 \%(2)$
Persamaan (2) merupakan rumus umum untuk menghitung nilai support dari suatu kombinasi item

\section{Confidence}

Akurasi dari suatu association rule sering disebut dengan confidence . Confidence atau dapat disebut nilai kepastian adalah kuatnya hubungan antar item dalam aturan asosiatif. Sebagai contoh pada aturan asosiasi $\mathrm{A} \Rightarrow \mathrm{B}$, menunjukkan seberapa sering item B dibeli jika konsumen membeli item A. Rumus untuk menghitung nilai confidence tersebut [12] yaitu

confidence $=\mathrm{P}(\mathrm{B} \mid \mathrm{A})=\frac{\text { Ltransasksi Adan B }}{\sum \text { transaksi } A}(3)$ untuk menentukan aturan asosiasi yang akan dipilih maka harus diurutkan berdasarkan support x Confidence. Aturan diambil sebanyak $\mathrm{n}$ aturan yang memiliki terbesar Prinsip kerja dasar dari algoritma ini yaitu dengan mengembangkan frequent itemset. Mulai dari satu item dan secara rekursif mengembangkan frequent itemset menjadi dua item, tiga item, dan seterusnya hingga frequent itemset tidak dapat dikembangkan lagi.

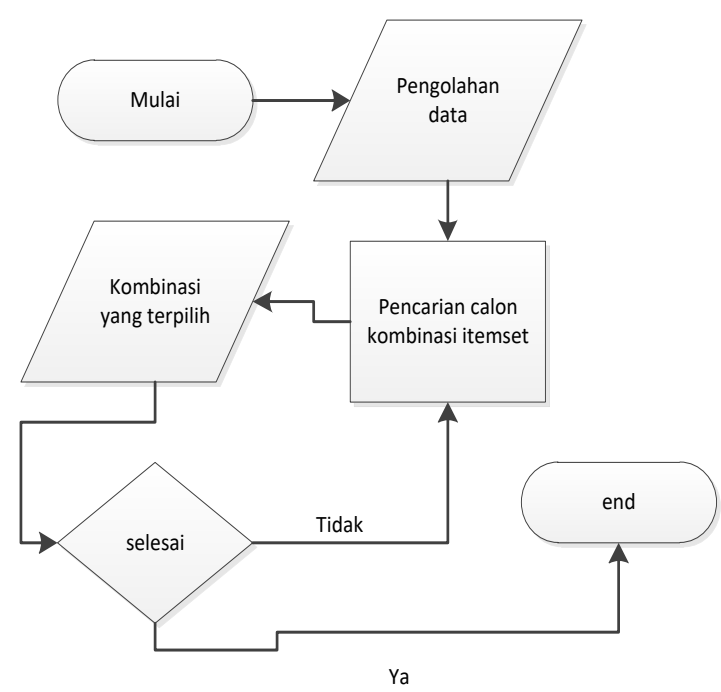

Gambar 1. Tahapan algoritma apriori imlementasi dai algoritma apriori dapat dilihat pada gambar 1. Dimana tahapan proses algoritma berjalan.

\subsection{Rapid Minner}

RapidMiner merupakan perangakat lunak yang bersifat terbuka (open source). RapidMiner 
adalah sebuah solusi untuk melakukan analisis terhadap data mining, text mining dan analisis prediksi. RapidMiner menggunakan berbagai teknik deskriptif dan prediksi dalam memberikan wawasan kepada pengguna sehingga dapat membuat keputusan yang paling baik.

cara pengunaan rapid miner pada penelitian ini sebagai berikut

1. mencatatkan transaksi penjulan sebagai berikut

Tabel 1. Format tabel data

\begin{tabular}{l|ll|l}
\hline $\begin{array}{l}\text { Trans } \\
\text { aksi }\end{array}$ & \multicolumn{1}{c}{$\begin{array}{l}\text { Nama_b } \\
\text { arang1 }\end{array}$} & $\begin{array}{l}\text { Nama_b } \\
\text { arang2 }\end{array}$ & $\begin{array}{l}\text { Nama_ba } \\
\text { rangN }\end{array}$ \\
\hline $\mathbf{0 0 1}$ & 1 & 0 & 1 \\
$\mathbf{0 0 2}$ & 0 & 1 & 1 \\
$\mathbf{N}$ & $\ldots$. & $\ldots \ldots$ & $\ldots \ldots$ \\
\hline
\end{tabular}

2. melakukan impor data pada repositori dengan browse tabel

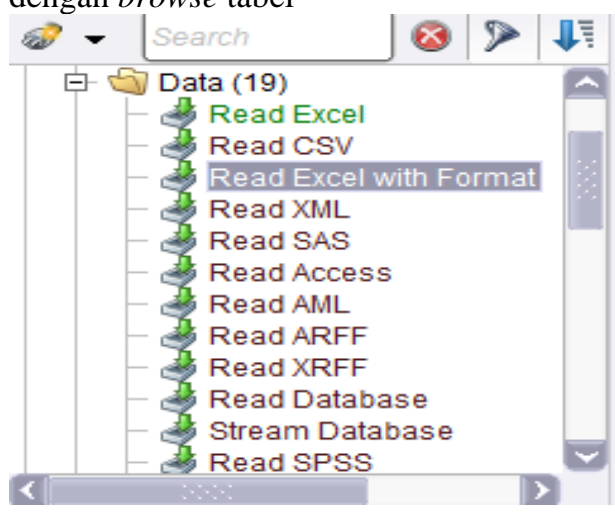

3. Kemudian aktifkan tiga buah oprator antara lain Numerical to Binominal, Assosiation Rule, FP-Growth dan , kemudian sambungkan oprator Assosiation Rule dengan FP-Growth. pada paremeter Assosiation Rule tentukan minimal confidence kemudian klik ikon play selanjutnya kembali pada operator FPGrowth ubah nilai minmum support, kemudian klik ikon play maka rapid miner akan menghasikan rule-rule yang memenuhi ketentuan.

KDnuggets, sebuah portal data-mining pada 2010-2011. RapidMiner menyediakan GUI (Graphic User Interface) untuk merancang sebuah pipeline analitis. GUI ini akan menghasilkan file XML (Extensible Markup Language) yang mendefenisikan proses analitis keingginan pengguna untuk diterpkan ke data.

\section{HASIL DAN PEMBAHASAN}

Salah satu teknik dari datamining adalah analisis asosiasi atau association rule mining untuk menemukan suatu kombinasi item. analisa data dilakukan setelah semua data terkumpul, untuk menghasilkan kesimpulan berdasarkan aturan (rule). untuk menganalisa data penjulan diperlukan transaksi penjulan yang sudah terjadi. pada CV Princes Diary Samarinda data sampel dari data transaksi adalah sebanyak 936 data transasksi, dan terdapat 21 jenis barang yang diperjualbelikan.

Untuk detai jenis barang yang diperjulabelikan dapat dilihat pada tabel 1 . Daftar barang.

\begin{tabular}{|c|c|}
\hline No & Jenis Barang \\
\hline 1 & Jam Tangan \\
\hline 2 & Dompet \\
\hline 3 & Kaca Mata \\
\hline 4 & Tas \\
\hline 5 & Sepatu \\
\hline 6 & Balon \\
\hline 7 & bag \\
\hline 8 & Kaos Kaki \\
\hline 9 & Sarung Tangan \\
\hline 10 & Make Up \\
\hline 11 & Kalung \\
\hline 12 & Jepit \\
\hline 13 & Ikat Rambut \\
\hline 14 & Bros \\
\hline 15 & Cermin \\
\hline 16 & Masker Muka \\
\hline 17 & Tali Sepatu \\
\hline 18 & Bando \\
\hline 19 & Alat Make Up \\
\hline 20 & Kipas Angin \\
\hline 21 & Sisir \\
\hline
\end{tabular}

Untuk data transasksi, diambil sebanyak 936data yang dapat dilihat pada tabel 2

Tabel 3. Data transaksi

\begin{tabular}{c|l}
\hline No & \multicolumn{1}{|c}{ Transaksi } \\
\hline $\mathbf{1}$ & Kaos Kaki, Kalung, Jepit \\
\hline $\mathbf{2}$ & Dompet Kaca mata, bag, masker muka \\
\hline $\mathbf{3}$ & Kaca Mata, Kalung, Bros, Alat Make up \\
\hline $\mathbf{4}$ & Tas Make Up \\
\hline
\end{tabular}




\begin{tabular}{|c|l|}
\hline $\mathbf{5}$ & Jepit, Jam Tangan, Kaos Kaki \\
\hline $\mathbf{6}$ & $\begin{array}{l}\text { Kalung, Alat Make Up, Make Up, Kipas } \\
\text { Angin }\end{array}$ \\
\hline $\mathbf{7}$ & Dompet, Ikat Rambut, Alat Make Up \\
\hline $\mathbf{8}$ & Ikat Rambut, Jepit, Alat Make Up \\
\hline $\mathbf{9}$ & Sisir, Make Up, Jam Tangan \\
\hline $\mathbf{1 0}$ & Jam tangan \\
\hline $\mathbf{1 1}$ & Sarung Tangan, Kaos Kaki, Bros \\
\hline $\mathbf{1 2}$ & Bros \\
\hline $\mathbf{1 3}$ & Jepit, Make Up \\
\hline $\mathbf{1 4}$ & Sisir, Make Up, Bando, Alat Make Up \\
\hline $\mathbf{1 5}$ & Bag, BAlon, \\
\hline $\mathbf{1 6}$ & Dompet \\
\hline $\mathbf{1 7}$ & Jepit, Make Up, Sisir, Masker Muka, Alat \\
\hline $\mathbf{1 8}$ & Make Up \\
\hline $\mathbf{1 9}$ & Jam Tangan, Dompet \\
\hline $\mathbf{2 0}$ & Jepit, Kalung, \\
\hline $\mathbf{2 1}$ & Alat Make Up, \\
\hline $\mathbf{2 2}$ & Kalung, Jepit, \\
\hline $\mathbf{2 3}$ & Make Up, Tas \\
\hline $\mathbf{9 3 4}$ & Dan Seterusnya ........... \\
\hline $\mathbf{9 3 5}$ & Siat Make up, Ikat Rambut, kalung,Kaca Mata \\
\hline $\mathbf{9 3 6}$ & Make up, Jepit, kalung \\
\hline & \\
\hline
\end{tabular}

selanjutnya memubuat data tabular. data tabular adalah data deskriptif yang menyatakan nilai dari data grafik yang diterang. Data ini biasanya berbentuk tabel terdiri dari kolom dan baris. Kolom menyatakan jenis data (field). Sedangkan baris adalah detail datanya (record). Data yang sudah diolah sehingga menjadi data tabular dapat dilihat pada gambar 1 .

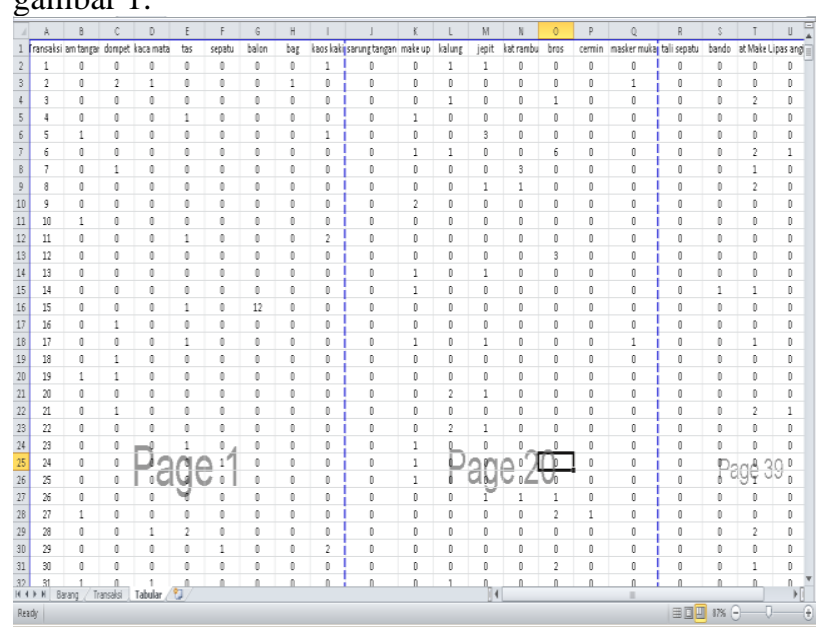

Gambar 1. Pengolahan data pada excel sehingga mengahasilkan tabel tabular yang siap di import ke rapidminer.
Setelah memiliki tabel tabular dengan data yang di dapat dari CV. Princess Diary Samarinda, maka lanjut ke tahap selanjutnya yaitu import ke RapidMiner untuk proses pengelolahan data menggunakan RapidMiner. Berikut cara-cara pegelolahan RapidMiner serta penjelasannya :

1. Import Data adalah anda mengupload data dari sumber eksternal melalui Analytics, lalu mengelolah dan menganalisis semua data dengan cara yang lebih mudah. Mengupload data pada RapidMiner dapat dilihat seperti gambar 2.

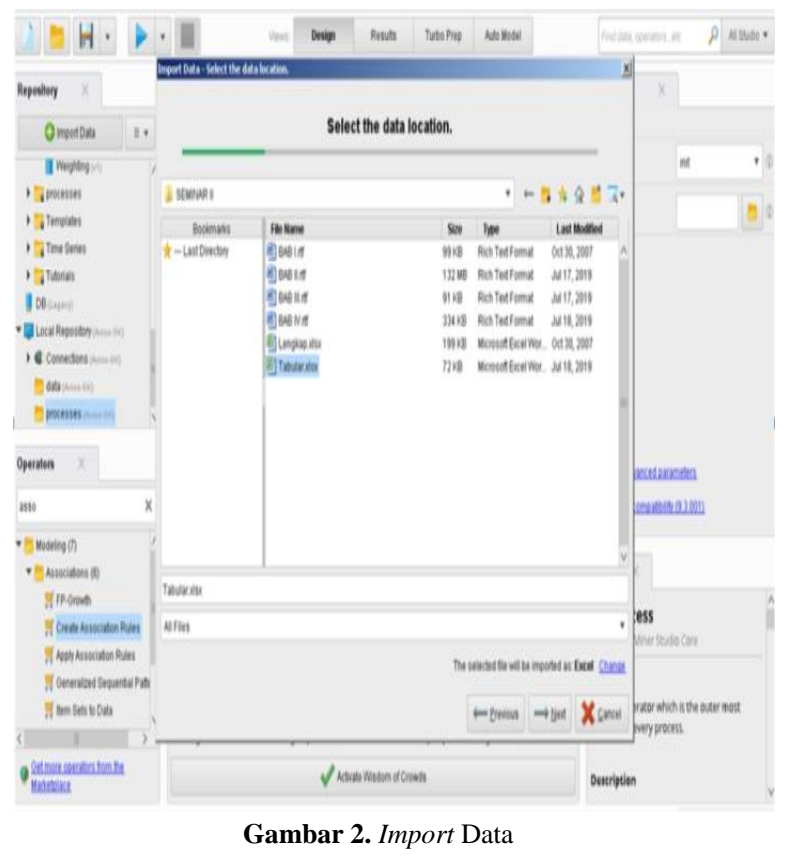

2. Drag and drow data pada local repository ke process. Untuk lebih jelasnya dapat dilihat pada gambar 3

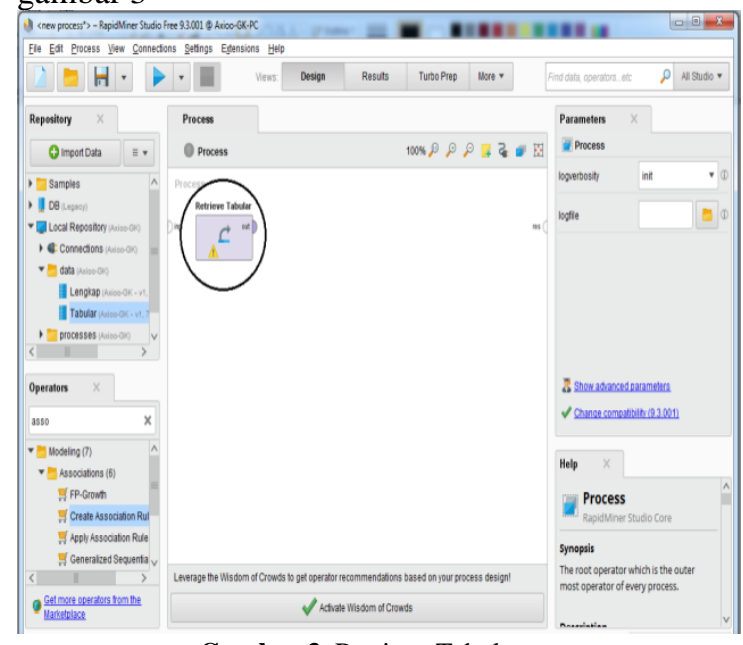

Gambar 3. Retrieve Tabular 
3. Pada menu operators klik Numerical To Binominal lalu drag and drow ke desain process. Numerical To Binominal bergunakan untuk merubah numerik ke bilangan Binominal yang di mengerti oleh RapidMiner. Nominal adalah Nilai secara kategori , Numeric adalah bilangan bulat. Hal ini dapat dilihat pada gambar 4 .

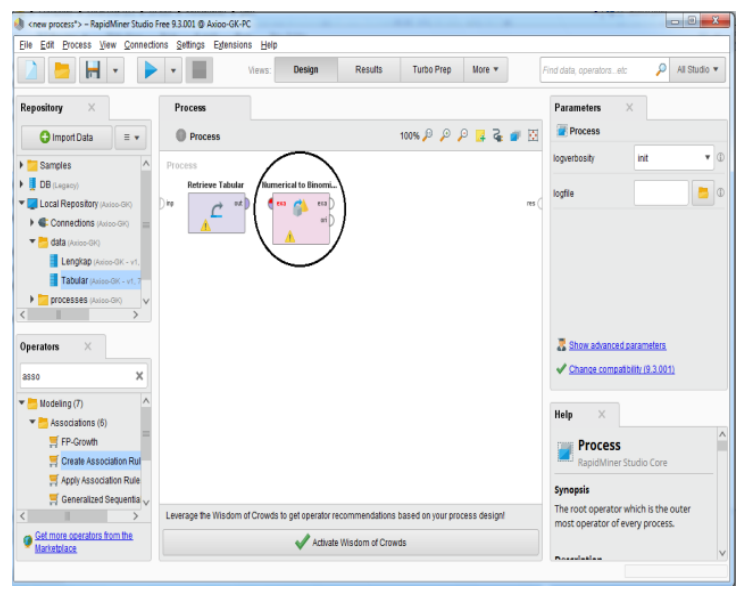

Gambar 4. Numerical To Binominal

4. Selanjutnya klik pada menu operators FpGrowth dan drag and drow ke process. FpGrowth untuk mengelola data \& dan melakukan filter data sesuai kriteria yang di miliki seperti minimum support yang muncul dari data itu saja. Untuk lebih detail dapat dilihat pada gambar 5.

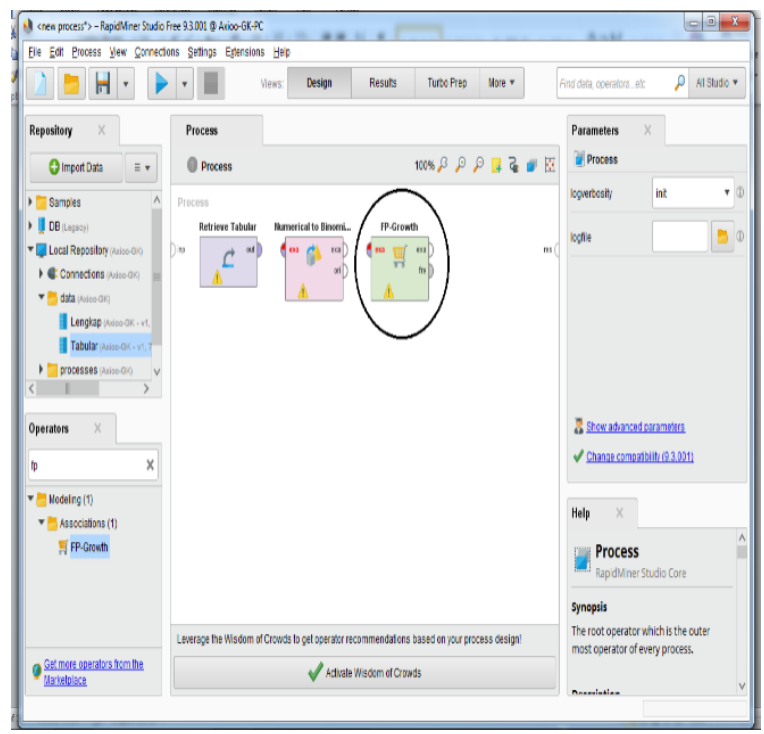

Gambar 5. Fp-Growth

5. Tahap selanjutnya yaitu Sambungkan Retrieve Tabular ke Numerical To Binominal lalu ke FpGrowth, lalu ke Create Association Rule, dan yang terakhir kita hubungan ke process result. Dan jangan lupa pada Fp-Growth minimum support di ubah 0.3 yang berarti minimum supportnya $30 \%$. dan pada Create Association Rule minimum confidence di ubah 0.5 yang bearti minimum confidence $50 \%$. Untuk lebih jelasnya dapat dilihat pada gambar 6

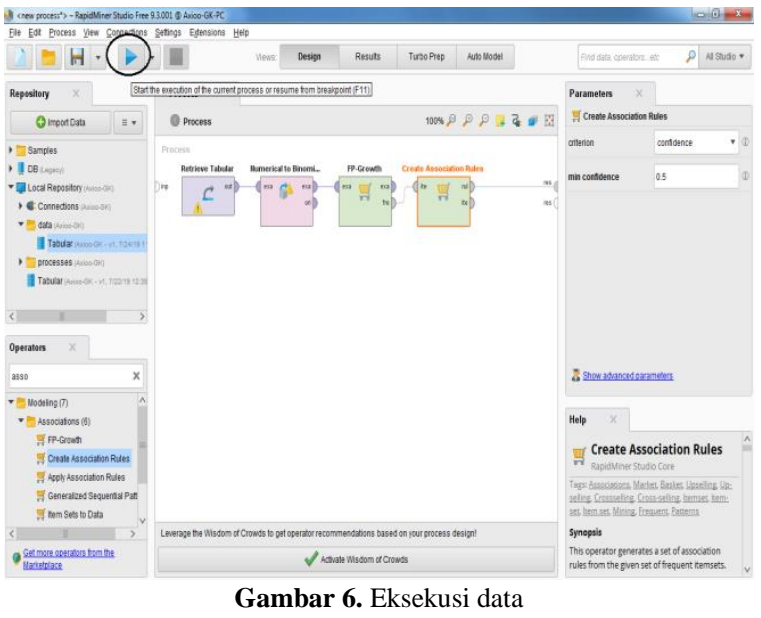

6. Langkah terakhir dari pemanfaatan aplikasi ini adalah menekan tombol RUN, yang akan langsung menganalisa data yang digunakan. Tampilan RapidMiner ketika di run atau start the execution. Data yang di hasilkan lebih sedikit karena minimum Support yang dipakai 0.3 atau $30 \%$ dan minimum confidence 0.5 atau $50 \%$. Untuk lebih jelasnya dapat dilihat gambar 7

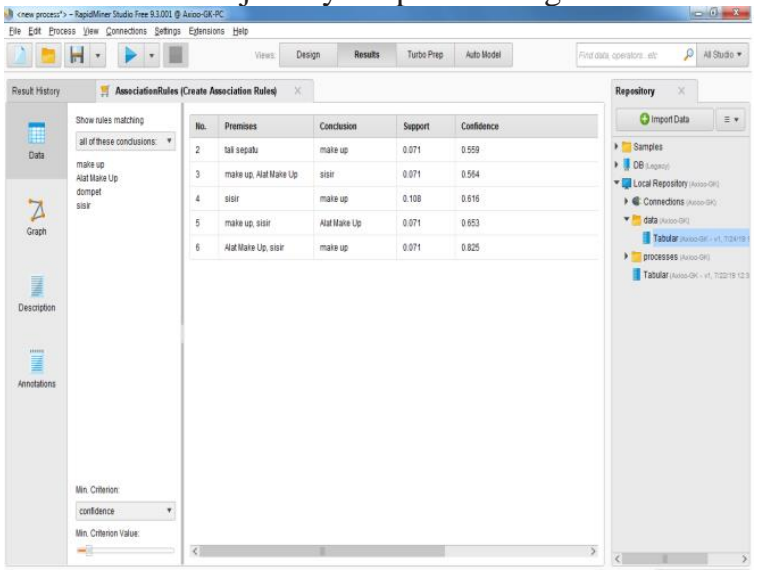

Gambar 7. Hasil Analisa.

Setelah semua pola frekuensi tinggi di temukan, barulah di cari aturan asossiasi yang memenuhi syarat minimum untuk confidence dengan menghitung confidence aturan asosiasi $\mathrm{A} \geq \mathrm{B}$.

Dari kombinasi 2 itemset yang telah ditemukan, dapat dilihat besarnya nilai support, dan confidence dari aturan asosiasi seperti tampak pada tabel dibawah ini :

Tabel 4. Aturan Asosiasi Rules

\begin{tabular}{ccc}
\hline Aturan & Support & Confidence \\
\hline Jika Membeli Kaca Mata , Maka & $0.525 \%$ & $0.559 \%$ \\
\hline
\end{tabular}




\begin{tabular}{l|c|c}
\hline akan Membeli Dompet & & \\
\hline $\begin{array}{l}\text { Jika Membeli Tali Sepatu, Maka } \\
\text { akan membeli Make up }\end{array}$ & $0.559 \%$ & $0.564 \%$ \\
\hline $\begin{array}{l}\text { Jika membeli Make Up, Maka } \\
\text { akan membeli Alat Make Up dan } \\
\text { sisir }\end{array}$ & $0.564 \%$ & $0.616 \%$ \\
\hline $\begin{array}{l}\text { Jika Membeli sisir maka akan } \\
\text { membeli make up }\end{array}$ & $0.616 \%$ & $0.653 \%$ \\
\hline $\begin{array}{l}\text { Jika membeli Make Up, maka } \\
\text { akan membeli sisir dan Alat Make } \\
\text { up }\end{array}$ & $0.653 \%$ & $0.653 \%$ \\
\hline $\begin{array}{l}\text { Jika membeli Make Up, Maka } \\
\text { membeli sisir dan alat make up }\end{array}$ & $0.825 \%$ & $0.825 \%$ \\
\hline
\end{tabular}

\section{KESIMPULAN}

1. Rapid minner dapat digunakan untuk mengalisa data penjulan dengan mengimplementasikan algoritma Apriori.

2. Didaptkan hasil dari asosiasi rule dengan nilai nilai confidence 0,5 atau $50 \%$ dengan nilai minimum supportnya 0.3 atau $30 \%$ didapatka hasil 6 buah aturan atau rule yang bisa digunakan untuk strategi penjulan

a) Jika membeli kaca mata maka akan membeli dompet ( dengan nilai support $52,5 \%$ dan confidence $55,9 \%$ )

b) Jika membeli tali sepatu maka akan membeli make up dengan nilai support $55,9 \%$ dan confidence $56,4 \%$ )

c) Jika membeli make up, Maka akan membeli alat make up dan sisir ( dengan nilai support $56,4 \%$ dan confidence $61,6 \%)$

d) Jika Membeli sisir maka akan membeli make up ( dengan nilai support 61,6\% dan confidence $65,3 \%$ )

e) Jika membeli Make Up, maka akan membeli sisir dan Alat Make up ( dengan nilai support $65,3 \%$ dan confidence $65,3 \%)$

f) Jika membeli Make Up, Maka membeli sisir dan alat make up ( dengan nilai support $82,5 \%$ dan confidence $82,5 \%$ )

3. Aturan diatas bisa digunkan sebagai bahan stategi penjualan dengan memasangkan produk pertama dengan produk kedua dengan memberikan harga yang menarik

\section{REFERENSI}

[1] R. Yanto and R. Khoiriah, "Implementasi Data Mining dengan Metode Algoritma Apriori dalam Menentukan Pola Pembelian Obat," Creat. Inf.
Technol. J., vol. 2, no. 2, p. 102, 2015, doi: 10.24076/citec.2015v2i2.41.

[2] S. Kasus, P. Pt, G. Gunadi, and D. I. Sensuse, "PENERAPAN METODE DATA MINING MARKET BASKET ANALYSIS TERHADAP DATA PENJUALAN PRODUK BUKU DENGAN MENGGUNAKAN ALGORITMA APRIORI DAN FREQUENT PATTERN GROWTH ( FPGROWTH ) :," vol. 4, no. 1, 2012.

[3] S. Qomariah, H. Ekawati, and S. Belareq, "IMPLEMENTASI METODE DATA MINING APRIORI PADA APLIKASI PENJUALAN PT. TIGA RAKSA SATRIA," Komputasi J. Ilm. Ilmu Komput. dan Mat., 2020, doi: 10.33751/komputasi.v17i1.1747.

[4] L. Hakim and A. Fauzy, "Menggunakan Metode Association Rules," Univ. Res. Colloq., pp. 73-81, 2015.

[5] A. Subhan and A. Z. Fanani, "Penerapan Data Mining Untuk Menentukan Potensi Hujan Harian Dengan Menggunakan Algoritma Naive Bayes," Mahasiswa.Dinus.Ac.Id, pp. 1-6, 2016.

[6] Y. Mahena, M. Rusli, and E. Winarso, "Prediksi Harga Emas Dunia Sebagai Pendukung Keputusan Investasi Saham Emas Menggunakan Teknik Data Mining," Kalbiscentia J. Sains dan Teknol., vol. 2, no. 1, pp. 36-51, 2015.

[7] A. Wibowo and S. Warnars, "Pengembangan Learning Characteristic Rule Pada Algoritma Data Mining Attribute Oriented Induction," J. Sist. Komput., vol. 6, no. 1, pp. 17-29, 2016, doi: 10.14710/JSK.V6I1.104.

[8] L. R. Angga Ginanjar Mabrur, "Penerapan Data Mining Untuk Memprediksi Kriteria Nasabah Kredit," J. Komput. dan Inform., vol. 1, no. 1, pp. 53-57, 2012.

[9] M. S. Mustafa, M. R. Ramadhan, and A. P. Thenata, "Implementasi Data Mining untuk Evaluasi Kinerja Akademik Mahasiswa Menggunakan Algoritma Naive Bayes Classifier," Creat. Inf. Technol. J., 2018, doi: 10.24076/citec.2017v4i2.106.

[10] A. Asosiasi and A. Apriori, "Keranjang Belanja Untuk Sistem Persediaan Alat-," pp. 1-9.

[11] M. Eka and R. A. Siregar, "Data Mining Assosiation Rule Untuk Mendukung Sistem Pencapaian Target Pajak Pendapatan Daerah Studi Kasus Di Kabupaten Deli Serdang," KOMIK (Konferensi Nas. Teknol. Inf. dan Komputer), vol. 2, no. 1, pp. 179-190, 2018, doi: 10.30865/komik.v2i1.979.

[12] F. A. Priyana and A. Kardianawati, "Data Mining Asosiasi Untuk Menentukan Cross-Selling Produk Menggunakan Algoritma Frequent Patern-Growth Pada Koperasi Karyawan PT . Phapros Semarang Sistem informasi yang terkomputerisasi organisasi dalam mengumpulkan berbagai data dalam suatu basis data," Ilmu Komput., pp. 1-7, 2015.

[13] IEICE Trans. Fundam. Electron. Commun. Comput. Sci., 2015, doi: 10.1587/transfun.E98.A.2010. 